\title{
Eradicating Squatters through Resettlement Programme: A Conceptual Paper
}

\author{
Julieven Nonoi Kuek ${ }^{1}$, Yusfida Ayu Abdullah ${ }^{2}$ and Hazlina Hamdan ${ }^{3}$ \\ ${ }^{1}$ Centre of Postgraduate Studies, Faculty of Architecture, Planning and Surveying, Universiti Teknologi MARA, 40450 Shah Alam, \\ Malaysia. \\ ${ }^{2}$ Centre of Studies for Town and Regional Planning, Faculty of Architecture, Planning and Surveying, Universiti Teknologi MARA, 40450 \\ Shah Alam, Malaysia. \\ ${ }^{3}$ Centre of Studies for Town and Regional Planning, Faculty of Architecture, Planning and Surveying, Universiti Teknologi MARA, 40450 \\ Shah Alam, Malaysia.
}

\begin{abstract}
The existence of squatters had caused many issues including poverty, increasing social problems, drug addiction, criminal and low education level. Sadly, the State of Johor is still among a few other states in Peninsular Malaysia with the highest numbers of squatter families. These squatter settlements are not only inhabited by the local people, but consist of foreigners too. The environmental condition is not fitting, with poor sewage system and unplanned housing construction. Consequently, these issues had caused bad images and perception to the general public, as well as to the tourists. In Malaysia, Resettlement Programme is one of the most significant mechanisms in tackling squatterse settlements issue. Hence, the Johor State Government had taken various approaches in trying to eradicate the squatter settlements by relocating them to new locations with planned and better housing. This conceptual paper aims to examine the current literature and assess previous similar study in order to establish an understanding of the crucial provision of resettlement area in trying to eliminate squatters. It employs a qualitative design through assessment related literature and studies. The results confirmed for a further review of resettlement program. Findings from this study further suggest a comprehensive study of the issues revealed.
\end{abstract}

\section{Introduction}

The issue of squatters is not a new phenomenon in Malaysia. A squatter house is one of the types of dwellings but is an illegal house built without permission from the local authority [1]. Illegal squatter housing relates to the establishment of houses without authority's approval including the land where the squatter settlements found and built their houses not in accordance with specification approved by the authority [2]. The UNHabitat [3] defines squatter as: (1) the occupants without guarantee of tenure land or residences; (2) neighbourhood without adequate or even cut off from basic facilities, (3) buildings or houses without planning approval or building regulations and often located in non-conducive living area.

Squatter problem has become alarming in many major cities since the rapid growth of cities had ultimately pushed more people to move and find a job in a city [4]. Additionally, the deficiency of supply of affordable housing had also resulted in the building of squatter buildings as another option to reduce the cost of living [4] since many of them cannot afford to purchase and own a property due to high pricing [5]. As a result of those underlying causes, the unfortunate group had no choice but to illegally build their houses at the squatter settlements despite the occurrence of various social problems and insufficient basic facilities at the area [6].

The latest data available on squatters shows that the State of Johor carries the highest number of squatter families as compared to other states in the Peninsular Malaysia with a total number of 6,363 families [7]. Here in Malaysia, squatters' areas are not only inhabited by the local people, but by foreigners too, including the illegal immigrants [8]. The existence of such areas had caused many problems including poverty, increasing social problems, drug addiction, criminal activities and low educational level among the residents [9]. Inevitably, the state of the environment which is often considered as non-environmental friendly including the impromptu housing construction and sewerage system had led to an unhealthy scene, revealing bad images to the general public and tourists. Tackling squatters through the Resettlement Programme is, therefore, one of the most important initiatives in eradicating squatters' problem in Malaysia. In trying to achieve this, the Johor state government had operated some approaches in relocating squatters including providing the squatters with

\footnotetext{
a Julieven Nonoi Kuek: julieven_kuek@yahoo.com
} 
provisional housing estates or even through public housing projects known as the "Project Perumahan Rakyat" (PPR), otherwise residing them to another area [10]. However, by taking any of these actions, the state government will deliberately discards their request and application or even concede their stay at any illegal housing area [10].

Nonetheless, even though resettlement programme is believed to be one of the solutions to wipe out squatter settlements, unavoidably, there appeared to be several issues and problems with regards to resettlement area; firstly, the location of resettlement areas are generally placed quite far from the city especially the newly built low-cost schemes [11] when most of the residents require the area to be close to their work place and schools [12] and secondly, the expensive price of houses for resettlement scheme particularly for those affected by the relocation program [12]. Even though the resettlement projects are subsidised, yet the total amount fixed by the developers is not within their capable budget and these problems frequently occur especially to the low-income group because the market price for low cost housing is still too expensive. Furthermore, the price of house is not included during the signing of purchase agreement, as well as the rate of bank loan, utility deposit, maintenance fee and other miscellaneous charges [13].

Moreover, the provision of resettlement houses was expressed to be uncomfortable [12]. Generally, the houses delivered for the resettlement residents indicates a lower standard of housing, seeing the compact building design and the use of lower quality of material. So, often the design and size of houses are among the major complaints from the residents of resettlement which claimed that the property cannot comfortably accommodate their family to reside [14]; [15]. Also, another problem is the issue of the resettlement houses being offered for rentals by the residents [12]. It became visible that some of the residents from the resettlement schemes rent out their low cost unit, but they themselves chose to stay elsewhere [15]. This occurs when the location of certain low cost units are at strategic sites offering opportunity for them to make profits from rentals.

Drawing from the basis of these continuing issues and problems, this paper sets out with an aim to appraise the existing literature and previous study of initiatives to eradicate squatters. It is anticipated that through this preliminary evaluation, it would be a beginning for a further advanced research of a resettlement program at the selected case study.

\section{Squatters and Resettlement Program}

\subsection{Definition of Squatters}

The UN-Habitat [3] defines squatter household as a group of individuals staying under the same roof in an urban area with one or more shortage(s) of the following components:

\section{Squatter Household}

- Durable housing made ffom permanent structure that protects against extreme climate conditions.

- Adequate living space; not more than three (3) people sharing the same room.

-Easy access to safe water and sometimes without charge.

- Access to adequate sanitation in the form of a private or public toilet shared by a reasonable number of people.

- Security of tenure that prevents forced evictions.

Figure 1: Definition of squatters' household as a group individuals living in the urban [3].

Meanwhile, Wakely [16] thought that squatters' houses feature unhealthy living situation and harmful locations, with hardship and social presence. Nevertheless, more appropriately, 'squatters' do not usually signify the informal settlements, but sometimes were planned development but have since physically worsened over time due to factors like overcrowding, or aging, or being neglected by the lower-income groups, etc. [17].

Generally, the squatter settlements in many major cities in the country have been in existence before Malaysia achieved its independence in 1957 [15]. One of the causes which influenced the development of squatters was urbanisation. Urbanisation was thought to have marked the three circumstances; (1) rural urban migration; (2) population growth; and (3) the redesignation of rural areas as urban [18]. Migration was therefore claimed to be its reason. However, migration takes place by force or voluntary. It can be influenced for reasons like being forced to reside to another area and remained at the new place due to natural disaster. Though, it can also be voluntary when people explore a new place for an improved economic prospect and a better life. There is also the 'pull' factor when rural migration is encouraged by the government, when people decide to work in factories or cheap labor. The main purpose for migrating to urban areas is to earn an income and a better future for themselves and their family whereas the condition of the shelters is not a priority. What is important is the proximity of their work place that involves minimal or not having to spend on transportation at all. To some, migration is temporary and they would, in the course of time, return to their villages hence renting a property becomes the best option. Hence, they would normally rent a place in squatter settlements where the rents are cheaper [15].

\subsection{Resettlement Program}

According to the United Republic of Tanzania [19], resettlement is identified as all procedures employed to mitigate all bad impacts, resulting directly to finishing off a project, on the livelihood of the project affected 
persons, their property as well as their compensation, relocation and rehabilitation. This action can be classified as any vulnerable and affected person including tribal communities, squatters and poverty group depending for livelihood upon the community in the project area and all those persons who may be exploited by the stronger or privileged persons located within the project area [19].

Based on International Finance Corporation [20], resettlement should be able to increase the quality of life of the people by score living standards ahead of the preproject levels. Resettlement must be intended and carry out as a development project over a minimum of two generations and comprises not only protective measures, but also the provision of new rights, resources and strategies [21]. The strategies taken by the government to resolve the problem of squatters throughout the country through relocation of the squatters may be positioned further away from their previous site. And these new settlement areas are usually equipped with the necessary infrastructure for better comfort to the squatters.

According to the UN-Habitat [22], relocation is a physical restoration measure which is expensive but can provide the basic needs for the poor society for those persisting to live in the urban areas. And so, resettlement is a method of balancing the socio-economic development of society. There are two approaches to resolve the issue of squatters; Firstly, by moving them to the land allocated to them by granting a lower land rate (nominal); and secondly, by providing them with lowcost flats (with low rental rate) or selling the flats at cheaper price.

Anyhow, the local authorities have the right to demolish any illegal settlement without paying any compensation so as to redevelop squatter areas in a more orderly environment yet have the obligation to maintain the area. Although this method is viewed as a positive tactic in terms of the physical condition but the economic aspect is not lucrative to the government [1]. In fact, the government had to spend a lot on the provisions when selling price is much cheaper, just to facilitate the squatters. The danger of this resettlement program is when the squatters refuse to be reallocated and decide to explore the presence of another vacant land

\section{Assessment of Previous Related Study}

This paper also discusses a previous research on "Issues and Policies on the Aftermath of Squatters Resettlement: A Case Study on Kampung Desa Hormat Tambahan, Selangor" by Ibrahim et.al, (2012), which mainly discusses about the issues and challenges encountered by the communities of squatters. Besides that, the study also considered the background and the residents' current living condition in a resettlement area in terms of racism, financial and compensation, along with the education aspect.

\subsection{Issues and Challenges of Squatters and Resettlement Area}

A multi-racism issue happens when the tragedy of May 1969 has given a big impact on shattering the multiracial relationship among the squatters' communities between Chinese, Indian and Malay families [12]. Frequently in the squatter's area, issues of water and electricity supply often not adequate and caused internal conflicts within the squatter community and therefore resulted one of the hindrance towards their harmonisation between the communities. Meanwhile, when looking at the problem of drainage and sewage systems it was found out that in squatters area there are no proper drainage provided. Hence, these causes the drainage to clog up with garbage and rubbish all the times [12].

The age of the resettlement community are from various aged group, ranged from toddler to old citizens. According to Ibrahim et al. [12] the residents have been living in the resettlement area for more than 10 years. Meanwhile the older citizens have been residing in the squatter's area for more than 30 years before moving to the new settlement. This low-cost area comprises of 8 blocks that can accommodate about 1600 people from different squatters area around Selangor. The resettlement area is mostly occupied by the Indian community $(65 \%)$ and another 35\% are Malay ethnic group [12].

However, when expressing about their current living condition, majority of the resettlement residents preferred to live in squatter area. This is because they felt burdened with financial obligations, where they were forced to take up the units whereas they were not given any compensation. By providing them with accommodation, they need to purchase the low cost unit with loan facilities of RM35,000 per unit. To make things worse, they need to pay other informal payments such as maintenance, donation, security and other miscellaneous costs [12]. The study also revealed that the residents claimed that the house is still unaffordable since most households are with monthly income around RM1,500 to RM2,000 per month, and with four to eight children [12]. Therefore, this indicates that the price of the resettlement units should be reviewed, unless the majority agree that the price is affordable. The price of the resettlement lowcost unit undeniably affects the poor.

It was discovered that one of the challenges of former squatters in a new place was racism due to the inadequacy of facilities in the resettlement area that causes disagreement of the facilities usage [12]. Sadly, another social issue also occurs associating with sexual misconduct. Therefore, the state government should ensure that the facilities are provided adequately and eligible to all communities.

Former squatters with financial problem are prone to move to a squatter place again. Majority of the residents required the government to give them funding instead of offering them accommodation [12]. To them, compensation would reduce their burden and can avoid poverty. Therefore, the process of resettlement had created hardship and difficulties to the residents of resettlement since they had to rent other property elsewhere before moving to the low-cost units. In terms of children education, parents were having difficulties to 
send their children to school due to financial constraints as some of their elder children had dropped out from schools and with no job at all [12].

Because of that, the government needs to take into account on the location factor and to ensure that resettlement projects are located within proximity as highlighted by the residents because discarding the location aspect could eventually causes difficulties to the residents of resettlement. Additionally, the low-cost unit price offered to the squatters would be best reviewed since majority of the residents were unable to purchase the unit.

\section{Evaluation of Successful Examples in Malaysia and Other Country}

\subsection{Selangor Successful Zero Squatters Programme}

In January 1998, the squatter settlements that were built were going to be demolished by the local authorities when the state government of Selangor encountered the growing issue by old and new squatter areas in Selangor [18]. Selangor has therefore introduced the 'Zero Squatter $2005^{\prime}$ action plan. Hence, the low-cost housing was developed in Selangor within five years ahead from February 2000 to December 2004 [18].

To accomplish Selangor Zero Squatters 2005 Action Plan, two main strategies were applied through five (5) approaches as stated below (Table 1):

Table 1: Selangor Zero Squatters 2005 Action Plan

\begin{tabular}{|l|l|}
\hline \multicolumn{2}{|c|}{ Selangor Zero Squatters 2005 Action Plan } \\
\hline Planning & $\begin{array}{l}\text { The government collected data on squatters and } \\
\text { low-cost houses. To confirm the provision of } \\
\text { adequate low-cost and medium cost houses for } \\
\text { target groups and squatter dwellers. }\end{array}$ \\
\hline Supervision & $\begin{array}{l}\text { Observing and ensuring that the development of } \\
\text { low cost-housing was based on schedule and } \\
\text { parallel to other types of development. }\end{array}$ \\
\hline Distribution & $\begin{array}{l}\text { To make sure that the distributions of low-cost } \\
\text { housing were efficient and fair to eligible target } \\
\text { group and squatter occupants. }\end{array}$ \\
\hline Enforcement & $\begin{array}{l}\text { Prevention and immediate enforcement that will } \\
\text { be conducted on any squatter settlements and } \\
\text { imposing measures on developers who failed to } \\
\text { develop low cost housing as planned and as } \\
\text { scheduled. }\end{array}$ \\
\hline $\begin{array}{l}\text { Housing } \\
\text { Management }\end{array}$ & $\begin{array}{l}\text { To make sure after December 2004, all } \\
\text { Selangor's residents will legally owned a home. }\end{array}$ \\
\hline
\end{tabular}

Source: Boonyabancha [28].

The local authorities played a vital role behind the implementation of Selangor Zero Squatters policies and also in resolving the squatter settlements issues. There were two units under this local authority namely, the secretariat and task force. The unit of secretariat was led by the assistant planner involved in all meetings related to squatters and the development of low-cost housing. This unit also checked the completion process in developing low-cost housing and handle the census, as well as the survey process of squatters [18].
Meanwhile, the task force unit involved the state assembly member to guarantee speedy development of low-cost housing and to assist in resolving issues with regards to low-cost housing and squatters. Nevertheless, the government of Selangor has to make sure some private developers will participate in the development of the low-cost housing [18]. From time to time the government of Selangor has to check the status from the developers. Every month developers had to submit their report and were required to explain their delay in completing low-cost housing. This was because most of the low cost housing were constructed on the site of the demolished squatter settlements. The success of Selangor in eradicating squatters also involved the negotiation with squatter occupants and the state assembly member and developers. The negotiation concerned more on the price and design of unit, temporary shelter and other compensation. The occupants of squatters were included in the process and were briefed about the Zero Squatter 2005 policy.

The relocation process was also one of the methods taken by the Selangor to abolish the squatter settlements. There are three types of relocation of squatter dwellers to low cost housing; (i) In-situ relocation where the squatter settlements site were previously allocated for low-cost housing development. Therefore, all the squatter dwellers from that area are listed on in-situ low cost housing scheme; (ii) Relocation within election zones by means if the sites of the squatter settlement were not developed for low-cost housing, other sites within an election zone will be identified for the development; and (iii) Relocation to the nearest election zones, if there were inadequate lowcost housing projects within an election zone, the area nearest to the election zone would be identified for development. This is the local authority's responsibility to identify the best criteria of the squatter dwellers and allocate them to the most suitable schemes [18].

Therefore it can be concluded here that the state government plays a vital role in eliminating squatter settlements, together with the local authorities in implementing the action plan to ensure that everyone in the whole state of Selangor would legally have their own house. Even though the Zero Squatters policy had not fully eradicate the squatters but the number had decreased in the major cities over the years in Selangor.

\subsection{Successful Thailand's Housing Programme for Squatters}

The Thailand government 2003 introduced "The Baan Mankong Program" through the Community Organisations Development Institute (CODI) in 2003. It was a program for the government targeting slum communities. According to Boonyabancha [28], the program was an important action in the process of transformation. Additionally, the Thai's National Housing Authority had also supported this squatters upgrading program through the help from the World Bank during the 1980s. Through this program about 30,000 to 50,000 of families in Thailand were improved. 
The Thai government formed the Urban Community Development Office in order to help the Community Organisations through loans for new housing as well as the improvement or upgrading of the income generation [28]. From 3,700 peoples of the poor community, about $30 \%$ of the community were squatters and another $70 \%$ rented the land which they stayed for a short term contract. These communities were under the risk of eviction, which is about $70 \%$ to $80 \%$ of the residents are not able to pay for conventional government housing programs [28].

There were two new programs introduced by the Thai government for the urban poor in January 2003; Firstly, the Baan Mankong (Secure Housing) Program, which required government funds in terms of development subsidies and housing loans to improve the present urban poor communities in enhancing their land, housing, environment and basic services that were fulfill by CODI [28]; and secondly, was the "Baan Ua Arthorn Program" where the National Housing Authority Designs of Thailand built and sold flats and houses at subsidies rates to the lower income households who managed to pay for "rent to-own" payments of 25 to 37 US dollar per month [28].

This Baan Mankong or secure housing program was built to assist the process designed and managed by lowincome households and their community organisations and networks. These communities and network work with local governments, professionals, universities and NGOs in their city to undertake surveys and review all the poor communities within three to four years [28]. After the plans have been finalized along with approved pilot projects, CODI will locate the development subsidies and housing loans straight to the communities. As Boonyabancha [28] stated, the type of upgrading will be decided during the discussion either on the same site or relocation, whether in public or private land, to sell to community or to be bought as a group. The power to make a decision was based on the community since the community is the owner of the project. Other than that, the community also have to take responsibilities to get loan for housing construction or obtain the land.

In addition, within 5 years the Baan Mankong had set a target to enhance the housing, living condition and tenure security for 300,000 households for the poor communities within 200 cities in Thailand. The programs started in 2003 by upgrading 1500 units of housing and the preparation in 20 cities. In year 2004, 174 squatter communities in 42 cities were and preparation of 50 cities. Meanwhile, year 2005 to 2007 are improving the 285,000 units of housing in 200 cities [28].

Moreover, there are various types of pilot projects that have been implemented by the Thailand's government, for examples, Land Purchase and Re-Blocking, Post Fire Reconstruction and A Long Term Lease, Relocation to Nearby Land, Scaling up pilot projects, land sharing, the Relocations of Mini Squatters and A Long Term Lease [28]. The pilot project of Land Purchase and Re-blocking involved 81 households in Charoenchai Nimitmai that stayed on 0.7 hectares in Bangkok near the railway tracks and drainage canal [28]. In 1998, the occupants had to move out from the area because they had rented the land from the land owners for many years. Hence the occupants negotiated to buy the land for a quarter of its market price [28]. Once they formed cooperative and they took CODI loan to pay it. They also created a re-blocking plan to reduce the cost per family that accommodated some other families who were squatting close by. Majority families constructed their homes using materials from their former houses. The communities made contract with the government hence received electricity and water supply and also building permits. All of these constructions were conducted by the occupants themselves and contractor had been employed by paid community labour that was 30 percent of total development cost. Each of the occupants was required to repay 25 to 50 US dollar every month to the Thai government [28].

Second example of pilot project implemented by the Thai government was Land sharing. Since 20 years ago, the canal side of Klong Lumnoon has been occupied. The areas were transformed in 1997 as agreed by the land owner to expel the people [28]. Approximately about 49 families who worked near the area refused to move out and some of them received compensation and moved away. However, about 49 numbers of families convinced the land owner to sell the land to them a small portion of land at below market value in exchange for emptying the rest. After registering as a cooperative, the community took loan to establish the CODI to buy the land as well as worked with the young architecture to build about 49 houses and space for community centre [28].

Another example was the Relocation of Mini Squatters and A Long Term Leases. Boon Kok was a new settlement in a central area of the northern Thai City of Uttaradit. It had about 124 households in many 'mini' squatter settlements [28]. The Thai government decided to buy 1.6 hectares site and grant the occupants a 30 years lease. The community network helped out through their daily savings schemes, and CODI offered housing loans to families that needed them, whereas the National Housing Authority provided the infrastructure. The communities needed to pay about USD5 to USD22.50 per month. Moreover, this settlement also included five (5) housing units for the elderly, the poor as well as the physical disabled member among the community [28].

Therefore, it can be concluded from the Baan Mankong Housing Program in Thailand, that the authorities, politicians and other groups in the city should be involved in negotiations with the urban poor group to address the city's housing problems. Moreover, the Thai government and the public support the programs for the poor communities. Hence, we can see that the communities or the people in Thailand are united to resolve the squatter problem. And it is proven that the Thai government encourages the squatters community to get involved with the construction of housing projects, forming their cooperative and take the Community Organisations Development Institute (CODI) loan to pay the land they had purchased or granted them grant for 30 years of lease. Malaysia can follow these strategies in resolving squatters issue where the community are not fully dependent on the government to solve the housing problems. 
mainly from the secondary sources.

\section{Research Methodology}

Based on the background and existing issues, this research, therefore, employs a case study design with a particular interest for Johor Bahru based on its features. Earlier, it was mentioned that the number of squatters in Johor Bahru is very high as compared to other states in Peninsular Malaysia (Table 2). Other than that, Johor Bahru was selected based on its geographical background; a significant urban area in the south of Peninsular Malaysia. The approach of study involved secondary sources which comprises of the literature on squatter settlements and resettlement program. The paper also appraised previous similar study by Ibrahim et.al [12] which focuses more on the issues of resettlement program. Future work would involve an in-depth interviews and questionnaire survey among the residents in Johor Bahru, along with site observation.

Table 2: The Significant Number of Squatters in Johor Bahru Source: Jabatan Perancangan Bandar dan Desa [7].

\section{Results and Discussion}

\begin{tabular}{|c|c|c|c|c|}
\hline No. & State & $\begin{array}{c}\text { No. of } \\
\text { Families }\end{array}$ & $\begin{array}{c}\text { No. of } \\
\text { Family } \\
\text { Members }\end{array}$ & $\begin{array}{c}\text { No. of } \\
\text { Squatters }\end{array}$ \\
\hline 1. & Johor & 6,363 & 22,151 & 5,922 \\
\hline 2. & Kedah & 2,702 & 13,274 & 2,702 \\
\hline 3. & Kelantan & 1,685 & 7,780 & 1,649 \\
\hline 4. & Melaka & 7 & 19 & 7 \\
\hline 5. & $\begin{array}{l}\text { Negeri } \\
\text { Sembilan }\end{array}$ & 314 & 585 & 239 \\
\hline 6. & Pahang & 1,134 & 3,339 & 935 \\
\hline 7. & Perak & 1,709 & 6,836 & 1,709 \\
\hline 8. & Perlis & 1,853 & 8,570 & 1,853 \\
\hline 9. & Pulau Pinang & 4,208 & 18,909 & 2,875 \\
\hline 10. & Sabah & 28,087 & 133,059 & 26,479 \\
\hline 11. & Sarawak & 8,085 & 32,354 & 7,784 \\
\hline 12. & Selangor & 2,542 & 3,299 & 3,299 \\
\hline 13. & Terengganu & 1,253 & 1,583 & 638 \\
\hline 14. & $\begin{array}{l}\text { Wilayah } \\
\text { Persekutuan } \\
\text { Kuala Lumpur }\end{array}$ & 3,217 & 12,868 & 3,217 \\
\hline 15. & $\begin{array}{l}\text { Wilayah } \\
\text { Persekutuan } \\
\text { Labuan }\end{array}$ & 970 & 5.521 & 976 \\
\hline \multicolumn{2}{|r|}{ Total } & 64,129 & 270,147 & 60,278 \\
\hline
\end{tabular}

This preliminary analysis was performed based on an early investigation of the case study in Johor Bahru. As mentioned much earlier, this initial results were obtained

Table 3: Housing Price Structure and Target Groups for State of Johor.

\begin{tabular}{|c|l|l|}
\hline Category & $\begin{array}{l}\text { House Price Per } \\
\text { Unit }\end{array}$ & $\begin{array}{l}\text { Target } \\
\text { Income Per Month }\end{array}$ \\
\hline Low Cost & RM25,000 & $\begin{array}{l}\text { Below RM2,500 per } \\
\text { month }\end{array}$ \\
\hline $\begin{array}{l}\text { Low Medium } \\
\text { Cost }\end{array}$ & RM50,000 & $\begin{array}{l}\text { RM2,500 - RM3,000 } \\
\text { per month }\end{array}$ \\
\hline $\begin{array}{l}\text { Low Medium } \\
\text { Cost }\end{array}$ & $\begin{array}{l}\text { RM80,000- } \\
\text { RM90,000 }\end{array}$ & $\begin{array}{l}\text { RM3,000 - RM4,500 } \\
\text { per month }\end{array}$ \\
\hline
\end{tabular}

\subsection{The practice of 'Zero Squatters'}

The Johor State Government had actively engaged in many initiatives to eradicate or reduce squatters within their boundary. This practice was seen significant through the commencement of the Zero Squatters Policy in 2005 [23]. Amongst the control undertaken were granting land ownership, Temporary Occupation License (TOL), and the shift to low-cost houses (PPR), and enforcement of land laws. In general, the federal government had implemented two programs to eliminate squatters' areas; namely the Zero Squatters program which helps to vacate the squatters' areas; and the Public Housing program for the new homes. Both of these programs were executed by the Johor state government. In fact, land ownership is the most common approach practiced by the state government, with the hope to reduce its expenditure and preventing it from paying compensation and transferring the people to a different area. At least, the government only suffer the de-valued of land.

\subsection{New Settlement Through Low Cost Housing Program}

Squatters are relocated to a new area through the Low Cost Housing Program which is carried out through the People's Housing Project or widely known as the Projek Perumahan Rakyat (PPR). Otherwise, they will be transferred at public housing under the Public Housing Division, the Office of the State Secretary of Johor. In any case, all costs including for construction of a new settlement will be certified by the party intending to develop the area. However, in Johor, the minimum area size for a low-cost housing development must be at least 5 acres. The Johor State Government has inflicted a condition requiring $40 \%$ of the total units in several housing scheme to be low cost housing, except in the case of the district of Johor Bahru where the low cost necessity is $30 \%$ (due to its high population over 1.0 million people [24] while another $10 \%$ low-medium cost houses are required for development as well [25]. This low-cost housing is therefore targeted for the squatters too. The price of a 3-bedroom low-cost house is RM25,000 while a low-medium cost house is RM50,000 (Table 3).

Through the various analysis on low-cost housing price, majority of the occupants of low-cost resettlement housing claimed that the house that they purchased are still expensive to them. This is because construction costs had increased. Generally, the cost of low-cost houses are more than RM30,000 per unit and does include the construction cost of infrastructure yet. Therefore, the situation of squatter's resident ability to buy low-cost housing remain as a major problem. 
Source: SUKJ Bahagian Perumahan [26].

\subsection{Resettlement Program}

As part of eradicating poverty and squatters, the state government had introduced numerous programs under the District and Land office, identified as the resettlement program [27]. The government believed that the issue of squatters and poverty has a connection with other social issues and by solving poverty and squatters, the government will indirectly resolve other social issues. The District and Land office will therefore determine new areas (the government's land) that are suitable for a resettlement program. Thereafter, the state government will acquire funding from the Ministry of Rural and Regional Development (MRRD) to build low-cost houses, along with other basic facilities and infrastructure. The eligibility for the low-cost houses is very much depended on their household income and the squatters will definitely be considered for the program. However, there are owners who moved out and rent their units to the outsider or immigrants or even foreigners. This is because they could not afford to buy the low-cost houses.

\subsection{Temporary Occupation License}

The state government also grants the Temporary Occupation License (TOL) to occupy government's land [27]. The land can be of road or river reserves, or land set aside for future development. However, the squatters will take advantage of the presence of vacant land to build their houses. For that reason, the government allows access to TOL for the squatters. This would, in turn, make them stay legally on government's land. Through this way, the government will not pay any compensation when acquiring back the land, therefore saving cost. Squatters often take advantage of vacant land to build buildings whether for residential or small business.

\subsection{Public Housing Program}

The National Economic Action Council (NEAC) has formed the Public Housing Program with the cooperation of the Ministry of Housing and Local Government to study on the condition of resettlement areas across the country [23]. Among the preparation is to form the Integrated Housing Program under the New Housing Policy for rental and ownership for the squatters [23]. The principle of this housing program acts as a platform in trying to accomplish the Zero Squatter policy. Through public housing, the less fortunate will have the chance to live in a better living condition. In addition, squatter who are involved in the redevelopment of their settlements cannot move in directly to low-cost flats. This is because the process for the redevelopment of squatters is very time-consuming. The residents will move only if low-cost flats are available and that they can buy the property.

\section{Recommendation and Conclusion}

Even though the Zero Squatters policy had been practiced since 2005 by most states in Peninsular Malaysia, Malaysia is still facing the issue of squatters and therefore introduced various approaches in order to tackle the problem. There are various approaches implemented by the Johor State government namely the practice of 'Zero Squatters' policy, low-cost housing program, resettlement programme, Temporary Occupation License (TOL) as well as Public Housing Program.

The research had also examined a previous related study by Ibrahim et.al [12] which discusssed on the resident's current living condition at squatter area, community background and the current living condition in a resettlement area, as well as the issues and challenges encountered by the former squatters in the new resettlement area. Briefly, from the previous related study by Ibrahim et.al [12], it demonstrates that the residents of the resettlement area were mainly reluctant to move out from their previous squatter area because they could not afford to purchase the low-cost housing. This finding was considered as important for the future whereby the government needs to consider the price of low-cost units in trying to accommodate the low-income group.

In addition, had also assessed an example of successful Zero Squatters program in Selangor and Thailand's Housing Program which targeted the poor and squatters. In Selangor, the initiative involved numerous strategies where the local authorities, task force unit as well as related responsible parties played a vital role in eradicating the squatter issues. This include the monitoring of low-cost housing projects and performing surveys to squatters, as well as ensuring some private developers will get involved in the development of the low-cost housing. Meanwhile, in Thailand, the approaches were slightly different. The government and the squatter or poor communities worked had in hand to resolve the problem by implementing squatter upgrading program in year 2003 through the Community Organisation Development Institute (CODI). Nevertheless, both Malaysia and Thailand's experience was considerably successful with the reduced number of squatters.

Based on the findings from the preliminary work of the case study, the study unveils the need to improve the current practice in Johor Bharu through several approaches as described below:

a. To continue with the Zero Squatters Initiative which stated in 2005. Even though the aim was not fully achieved but tio some extent it had reduced the number of squatters. For that reson, the target for year 2020 is highly recommended.

b. The state government's effort in building low-cost houses in Johor Bahru is part of its effort in assisting the low-income group, but most importantly to eliminate squatters in Johor Bahru. However, it was clearly revealed that the price of low-cost units are still beyond the squatters' availability or affordability. Therefore, the 
government should re-examine the current price and reconsider the need to reduce the price of low-cost housing.

c. The analysis showed the occurance of incidents where the residents of resettlement area rent their units to other people including illegal immigrants. This calls for a strict reinforcement by the authorities.

d. The practice of Temporary Occupation License (TOL) is a good exercise by the state government as it helps to overcome squatters through legal occupation of government land.

e. The state government of Johor can follow the practice of Thailand and Selangor in eradicating squatters. The Thai government allows the poor and squatters communities to be involved in the planning and provision of housing program for the poor. Meanwhile Selangor uses its task force to assist the government to eliminate squatters. These particular efforts can be a guidance to Johor Bahru.

From the overview and early conception of initiatives to eliminate squatters, the researcher will consequently undertake a methodical investigation on the proposed case study, i.e, a resettlement program in Johor Bahru. Further work in Johor Bahru will look at the delivery of the Johor Bahru resettlement program in order to enhance the initiative, and involve a survey among the community of the resettlement program, for the purpose of understanding in detail their experience and what can be improved in the future.

\section{Acknowledgement}

The authors would like to thank the Universiti Teknologi MARA (UiTM) for supporting this study and the Centre of Postgraduate Studies, FSPU.

\section{References}

1. S.Z. Kader, Eviction of Unlawful Occupiers of Land in Malaysia_Judical Responses and Policy. International Islamic University Malaysia (2011).

2.K.A. Mohamad, Kemiskinan Bandar: Penswastaan Kawasan Setinggan dan Peminggiran Sosial. Available at(http://www.pengurusanislam.tripod.com/kemiskaina n_bandar.htm), (2010).

3. UN-HABITAT, G. L. T. N. Handling Land-Innovative Tools for Land Governance and Secure Tenure. Nairobi, (2012)

4.M. Ariff, and H. Davies, Sustainable Living Environment for Urban low-income households in Malaysia: Key factors for maintenance. in CIBW 107,2009. Proceedings of the 2009 International Symposium on Construction in Developing Economies: Commonalities among diversities, CIBW, (Penang, Malaysia), (2009)

5. A. Ismail, A. A. Bujang, W. R. Anthony Jiram, H. Abu Zarin, and M. N. Jaafar, Housing Financing Faculity and Affordability Level of Bumiputera within Iskandar Malaysia. Journal of Economics, Business and Management, Vol. 3, No.9, September (2015)
6. M.T. Taher, , and A. Ibrahim, "Transportation of Slum and Squatter Settlements: A way of Sustainable Living in Context of $21^{\text {st }}$ Century Cities." American Journal of Civil Engineering and Architecture 2, No.2 (2014): 7076. (2014)

7. Jabatan Perancangan Bandar dan Desa. Laporan Kesejahteraan Rakyat. Selangor: Jabatan Perancang Bandar dan Desa. (2013)

8. Daily Express. Informal Housing Booming Due to ' 0 ' Squatters drive failure. Independent National Newspaper of East Malaysia. Established Since 1963. Published on: Monday, July 27, (2015). Retrieved: $01 / 11 / 2015$.

9. H. Wan. Kualiti hidup sosial dan proses perbandaran di Malaysia.Isu-isu alam sekitar manusia di Malaysia, Universiti Pendidikan Sultan Idris, Perak.pp. $19-42$. (2010)

10. A.Z. Asri. Squatter Houses in the Area of Johor Bahru. Thesis (Sarjana Kejuruteraan AwamPengurusan Pembinaan), Faculty of Civil Engineering, Universiti Teknologi Malaysia (2013)

11. S. Shuid. Low Income Housing Allocation System in Malaysia. Managing Housing Need for the Poor. Paper Presented at $22^{\text {nd }}$ International Housing Research Conference. Istanbul (2010)

12. I. Ibrahim, N.A. Aziz, F. Hussain, A. Noraini. Issues and Policies on Aftermath of Squatters Resettlement: A Case Study on Kg. Desa Hormat Tambahan, Selangor (2012)

13. Utusan Malaysia. "Kekecohan Pembelian PPR". Berita dalam akhbar Utusan Malaysia. Kuala Lumpur, Malaysia: 16 November (2009)

14. A.H. Hashim, Residential Satisfaction and Social Integration in Public Low Cost Housing in Malaysia. Department of Resource Management and Consumer Studies. Faculty of Human Ecology. Universiti Putra Malaysia (2003)

15. A. Sufian, and N.A. Mohamad, Squatters and Affordable Houses in Urban Areas: Law and Policy in Malaysia. International Islamic University Malaysia (2009)

16. P. Wakely, 'Land tenure in under-served settlements in Colombo', IDRC Urban Poverty and Environment Report Series 6, Ottawa: IDRC. (2008)

17.UN-HABITAT. Sustainable Urbanisation.Achieving Agenda 21. Department for International Development (2002)

18.F.A. Aziz, The Investigation of the Implication of Squatter Relocations in High Risk Neighbourhoods in Malaysia. School of Architecture, Planning and Landscape, Newcastle University (2012)

19.United Republic of Tanzania. Resettlement Policy Framework. Prime Minister's office-Regional Administration and Local Government. Available at: http://www.pmoralg.go.t2/menu_data/programmes/D M. (2012)

20.International Finance Corporation. Performance Standard5, Land Acquisition and Involuntary Resettlement. World Bank Group (2012)

21.Leopoldo, et.al,. Displacement, Resettlement, Rehabilitation, Reparation and Development, WCD 
Thematic Review 1-3 Prepared as an input to the world Commission on Dams, Cape Town, www.dams.org. (2000)

22.UN-HABITAT. State of the World's Cities Report. UN-HABITAT, Nairobi. (2010)

23. A. Atif. Masalah Setinggan di Johor Bahru: Masalah yang diundang. Available at (http://www.slideshare.net/ukhuwah_90/masalahsetinggan-bandar-Johor-Bahru. - (Retrieved: 30/11/2015). (2012)

24.Iskandar Regional Development Authority. Portal Rasmi IRDA (2014)

25.R. Zain. Setinggan dan Kemiskinan. Available at http://www.documents.tips/documents/setinggan-dankemiskinan-html.(Retrieved: 20/12/2015). (2015)

26.SUKJ Bahagian Perumahan. Available at: http://www.erumah.johor.gov.my/spj/home/hmsyarat permohonan.htm.(Accessed:12/12/2015). (2014)

27. H.M. Salehan, Kajian Terhadap Tindakan Kerajaan Negeri Johor Dalam Menangani Penempatan Semula Setinggan di Negeri Johor. Kajian Kes: Kampung Sri Rahmat, Johor Bahru. Fakulti Kejuruteraan dan Sains Geoinformasi. Universiti Teknologi Malaysia (2007).

28.S.Boonyabancha. Baan Mankong: Going to Scale with "Slum" and squatter upgrading in Thailand. Environment and Urbanisation Vol.7. Downloaded from eau.sagepub.com. (2005). Retrieved: 9 February, 2016. (2005) 